\title{
Impact of the proteolysis due to lactobacilli on the stretchability of Swiss-type cheese
}

\author{
Romain RichOUX*, Lydie AuBERT, Grégory RoseT, Jean-René KERJEAN
}

Actilait, BP 50915, 35009 Rennes Cedex, France

Received 10 January 2008 - Accepted 31 March 2008

\begin{abstract}
Proteolysis is known to be a key factor for cheese stretchability. However, proteolysis in Swiss cheese is rather limited because of the inactivation of rennet during cooking. To determine the contribution of the main agents of Swiss cheese proteolysis, experimental cheeses were manufactured with various Lactobacillus cultures or with various amounts of plasmin added. Marked differences in stretchability were observed among the Lactobacillus cultures. Lactobacillus helveticus strains yielded higher stretchability than Lactobacillus delbrueckii subsp. lactis strains and than mixed cultures of both species. Plasmin addition improved the stretchability at the early stages of ripening (cold room ripening) only. Strong relationships were observed between the proportion of hydrophobic peptides in the fraction of $\mathrm{pH}$ 4.6-soluble nitrogen and cheese stretchability. These results show that Lactobacillus culture is a key factor for Swiss cheese stretchability and suggest the involvement of hydrophobic soluble peptides in Swiss cheese stretchability.
\end{abstract}

stretchability / Swiss-type cheese / proteolysis / Lactobacillus helveticus / Lactobacillus delbrueckii subsp. lactis

摘要 - 蛋白水解对瑞士干酪拉伸性的影响。蛋白质水解是干酪拉伸性能的一个关键参数。 然而在瑞士干酪中由于凝乳酶失活使得蛋白质的水解程度较低。为了测定瑞士干酪中引起 蛋白质水解的主要原因, 采用不同的乳杆菌发酵剂或者加入不同量的血纤维蛋白溶酶制成 平酪样品。用不同乳杆菌发酵剂制成的干酪之间, 干酪的拉伸性能具有显著性的差异。使 用 Lactobacillus helveticus 发酵剂的干酪拉伸性高于单独使用 Lactobacillus delbrueckii subsp. lactis 菌株和上述两株混合菌株的干酪拉伸性。血纤维蛋白溶酶的加入只能是在成熟初期 (低温成熟) 改进了干酪的拉伸性。 $\mathrm{pH} 4.6$ 可溶性氮中疏水性肽的比例与干酪拉伸性能具有 非常强的相关性。研究结果证明, 乳杆菌发酵剂是影响瑞士干酪拉伸性能的关键因素, 可溶 性氮中疏水性肽含量也影响瑞士干酪的拉伸性。

拉伸性 / 瑞士干酪 / 蛋白质水解 / Lactobacillus helveticus / Lactobacillus delbrueckii subsp. lactis

Résumé - Impact de la protéolyse des lactobacilles thermophiles sur les propriétés filantes de l'emmental. La protéolyse des fromages joue un rôle déterminant dans leur aptitude à filer à chaud. Dans les fromages à pâte pressée cuite, la protéolyse est cependant limitée en raison de l'inactivation de l'enzyme coagulante pendant l'étape de cuisson. Pour déterminer la contribution des deux principaux agents protéolytiques de l'emmental, des fabrications expérimentales ont été réalisées en mettant en œuvre différentes cultures de lactobacilles thermophiles et différents niveaux d'addition de plasmine dans le lait. De fortes disparités de propriétés filantes ont été observées selon la culture de lactobacille utilisée. Les souches de Lactobacillus helveticus ont conduit à de fortes propriétés

* Corresponding author (通讯作者): r.richoux@actilait.com 
filantes comparativement aux souches de Lactobacillus delbrueckiii subsp. lactis ou aux cultures mixtes associant des souches de ces deux espèces. L'addition de plasmine n'a augmenté les propriétés filantes des fromages qu'aux premiers stades de l'affinage (cave froide). Pour ces deux types d'expérimentations, de fortes relations entre la longueur des fils et la proportion de peptides hydrophobes dans l'azote soluble ont pu être établies. Ces résultats montrent que le choix de la culture de lactobacille thermophile est un facteur clef des propriétés filantes de l'emmental. Ils suggèrent également la participation de peptides hydrophobes solubles dans le mécanisme de formation des fils d'emmental fondu.

filant / emmental / protéolyse / Lactobacillus helveticus / Lactobacillus delbrueckii subsp. lactis

\section{INTRODUCTION}

A growing part of the cheeses produced worldwide is consumed in hot dishes [14] such as pasta, pizza, burgers, gratin, fondue, etc. Thus, the functional properties of melted cheese become a major criterion of cheese quality. Stretchability, which refers to the ability of melted cheese to form strings, is one of the main functional properties. Depending on the cheese variety and its utilisation, stretchability can be considered as a quality (Mozzarella and other pasta-filata cheeses, Swiss cheese) or a defect (Raclette cheese) [7,8]. The control of the factors involved in this property is of practical relevance.

The stretchability of cheese depends on its gross composition, $\mathrm{pH}$, mineralisation and proteolysis. Homogenisation or strong heat treatment of the cheesemilk as well as the incorporation of denatured whey proteins have also been shown to alter stretchability $[8,15]$. It has been well established that cheese stretchability is modified during ripening [8]. Generally, the stretchability reaches a maximum after a few weeks and then decreases. These changes have been mainly related to proteolysis, and particularly to the action of residual rennet.

In hard cooked cheese such as Swiss cheese, the coagulating enzyme is inactivated during the cooking step $\left(>50{ }^{\circ} \mathrm{C}\right)$ and proteolysis is mainly due to plasmin and starter activities [5]. Thermophilic lactobacilli (Lactobacillus helveticus or
Lactobacillus delbrueckiii subsp. lactis or both) are the most proteolytic starters used in Swiss cheese technology.

In Low Moisture Part Skim (LMPS) Mozzarella, the rod:coccus ratio and the use of specific strains of these species have been shown to influence proteolysis and stretchability [11, 16, 17, 23]. Hong et al. [11] found strong differences in stretchability when comparing three commercial strains of L. helveticus or L. delbrueckii subsp. bulgaricus with marked differences in proteinase and aminopeptidase activities. In this study, a strong proteolytic-low peptidasic $L$. delbrueckii subsp. bulgaricus strain gave the strongest stretchability. Oberg et al. [16] showed that proteinase-deficient strains of $L$. delbrueckii subsp. bulgaricus yielded to a weaker "stretchability" (helical viscosity) than proteinase-positive strains. Further, Oomen et al. [17] suggested that the specificity of cell-wall proteinase could be involved in the stretchability potential of L. delbrueckii subsp. bulgaricus. These authors found a "qualitative" effect of the strains on the number and the width of the strings, rather than their length.

The aim of this study was to investigate the influence of cultures of thermophilic lactobacilli and plasmin addition on the stretchability of Swiss-type cheese and to identify nitrogen fractions related to stretchability. In this way, this study aimed to contribute to the understanding of the mechanisms of stretchability. 
Table I. Overview of lactobacilli cultures used for the production of the experimental Swiss-type cheeses.

\begin{tabular}{lcccc}
\hline Culture & Species & Commercial name & Supplier & Form \\
\hline H1 & LH77 & Standa $^{1}$ & FD-SVI $^{6}$ \\
H2 & L. helveticus & ISLC 5 & ISLC $^{2}$ & FC $^{7}$ \\
H3 & CNRZ 32 & INRA $^{3}$ & FC $^{7}$ \\
& & & & \\
L1 & & ITG LL14 & ITFF $^{4}$ & FC $^{7}$ \\
L2 & L. delbrueckii subsp. lactis & ITG LL45 & ITFF $^{4}$ & FC $^{7}$ \\
L3 & & LL51 & Standa $^{1}$ & FD-SVI $^{6}$ \\
& & & & \\
M1 & L. helveticus + & LH1-LL51 & Standa $^{1}$ & FD-SVI $^{6}$ \\
M2 & L. delbrueckii subsp. lactis & LH56-LL57 & Standa $^{1}$ & FD-SVI $^{6}$ \\
M3 & & LH 100 & Danisco $^{5}$ & FD-DVI $^{8}$ \\
\hline
\end{tabular}

${ }^{1}$ Laboratoires Standa, Caen, France.

${ }^{2}$ Istituto Sperimentale Lattiero Caseario, Lodi, Italy.

${ }^{3}$ Institut National de la Recherche Agronomique, Jouy-en-Josas, France.

${ }^{4}$ Institut Technique Français des Fromages, Bourg-en-Bresse, France.

${ }^{5}$ Danisco, Dangé-Saint-Romain, France.

${ }^{6}$ Freeze-dried culture for Semidirect Vat Inoculation.

${ }^{7}$ Frozen culture.

${ }^{8}$ Freeze-dried for Direct Vat Inoculation.

\section{MATERIAL AND METHODS}

\subsection{Bacterial strains and culture conditions}

A total of 9 commercial cultures including pure and mixed strains of L. helveticus and L. delbrueckii subsp. lactis were tested in experimental cheesemaking. The bacterial composition, commercial name, supplier and application form of the tested culture are listed in Table I.

Frozen cultures were thawed overnight at $4{ }^{\circ} \mathrm{C}$ and grown at $44{ }^{\circ} \mathrm{C}$ until $0.65 \%$ acidity in ionised skim milk (LaitG, Laboratoires Standa, Caen, France) reconstituted $(10 \% \mathrm{w} / \mathrm{w})$ in autoclaved water with $0.5 \%$ yeast extract. A subculture was made at $44{ }^{\circ} \mathrm{C}$ until $1.1 \%$ acidity in a specific medium (Phagex LB, Laboratoires Standa) reconstituted at $13.5 \%$ and heat-treated at $85{ }^{\circ} \mathrm{C}$ for $30 \mathrm{~min}$. Freeze-dried cultures for semidirect vat inoculation (FD-SVI) were directly grown in Phagex medium as described above. For both types of cultures, $3 \mathrm{~mL}$ of Phagex culture were added to cheesemilk (about $10^{5} \mathrm{cfu} \cdot \mathrm{mL}^{-1}$ ). Freezedried cultures for direct vat inoculation (FD-DVS) were directly added to the vat.

A FD-SVI culture of Streptococcus thermophilus (PAL-ITG ST20-87, Laboratoires Standa) was grown in $13.5 \%$ reconstituted Marstar 412A (Danisco, Dangé-Saint-Romain, France) until 0.95\% acidity. Then $12 \mathrm{~mL}$ of this culture (about $10^{6} \mathrm{cfu} \cdot \mathrm{mL}^{-1}$ ) were added per litre of cheesemilk.

\subsection{Cheesemaking}

Small-scale Swiss-type cheeses (800 g) were manufactured from microfiltered skim milk standardised with heat-treated cream $\left(115{ }^{\circ} \mathrm{C}\right.$ for $\left.20 \mathrm{~s}\right)$ using a standardised process as described by Richoux and 
Kerjean [19]. Briefly, the milk was ripened with starters at $32{ }^{\circ} \mathrm{C}$ for $60 \mathrm{~min}$ and coagulated by the addition of calf rennet. The gel was cut into curd grains of $4 \mathrm{~mm}$ mean diameter. After $15 \mathrm{~min}$ of foreworking, the whey-curd mixture was cooked at $53.5{ }^{\circ} \mathrm{C}$ for $33 \mathrm{~min}$. The duration of stir-out was $45 \mathrm{~min}$. The curd was then moulded into forms with a diameter of $12 \mathrm{~cm}$.

The pressing step $(6 \mathrm{~h})$ and the acidification step $(14 \mathrm{~h})$ were conducted in thermostated ovens at $48{ }^{\circ} \mathrm{C}$ and $36{ }^{\circ} \mathrm{C}$, respectively, in order to mimic the cooling rate of the centre of an 80-kg full-size Emmental wheel. The cheeses were then cooled and salted for $5 \mathrm{~h}$ in a $\mathrm{NaCl}$-saturated brine at $7{ }^{\circ} \mathrm{C}$. The cheeses were wrapped under vacuum in BK1L-ripening bags (Cryovac, Epernon, France) and ripened at $12{ }^{\circ} \mathrm{C}$ for 21 days, at $24{ }^{\circ} \mathrm{C}$ for 21 days and then at $4{ }^{\circ} \mathrm{C}$ for 5 days.

Porcine plasmin (EC3.4.21.7, SigmaAldrich, Saint Quentin Fallavier, France) was added to the cheesemilk (1.1 or $2.2 \mathrm{U} \cdot \mathrm{L}^{-1}$ ) in some experiments made with M1 culture to test its effect on cheese stretchability.

\subsection{Cheese analysis}

The cheeses were analysed for moisture [13], fat [10], $\mathrm{NaCl}$ (potentiometric method) and calcium [18]. Total nitrogen (TN), $\mathrm{pH}$ 4.6-soluble nitrogen (SN) and $12 \%$ TCA-soluble nitrogen (NPN) were determined according to Gripon et al. [6] using the Kjeldahl method [12]. Casein breakdown was evaluated by urea-PAGE of the $\mathrm{pH}$ 4.6-insoluble nitrogen according to Collin et al. [3].

Cheese stretchability (3 replicates per sample) was assessed by a method involving vertical traction of melted cheese $\left(82{ }^{\circ} \mathrm{C}\right.$ ) according to Richoux et al. [20]. The length $(\mathrm{mm})$ of the cheese strands was measured. The coefficient of variation of repeatability was about $15 \%$.

\subsection{Experimental design}

The results presented in this study were obtained from three independent experiments conducted within a short period ( 2 weeks) and with the same batch of microfiltered milk. In the first experiment, four Lactobacillus cultures (H1, L1, L2 and M1) were tested (three replicates per strain). In the second experiment, cheeses were made with the M1 culture with or without plasmin addition (3 replicates). In the third experiment, various lactobacillus cultures were tested : $\mathrm{H} 1(n=8), \mathrm{H} 2$ $(n=2)$, H3 $(n=2)$, L3 $(n=3)$, M2 $(n=8)$ and M3 $(n=9)$. Cheeses without lactobacilli addition were also made during the third experiment $(n=2)$.

Cheese proteolysis and stretchability were measured at day 7, day 21 (end of cold room ripening) and day 49 (ripened cheeses), except in the third experiment, in which cheeses were analysed at day 49 only.

\subsection{Statistical analysis}

Analyses of variance (ANOVA) were performed using the General Linear Model procedure of Statbox V6.3 (GrimmerSoft, Paris, France). Differences between the treatment means were compared at the $5 \%$ level of significance using Fisher's least significance difference (LSD) test.

\section{RESULTS}

\subsection{Cheesemaking and composition of cheeses}

Lactobacillus culture or plasmin addition had little impact on the cheesemaking parameters (data not shown). The cheeses manufactured with $L$. helveticus strains alone (H cheeses) showed a significantly $(P<0.05)$ slower acidification at 


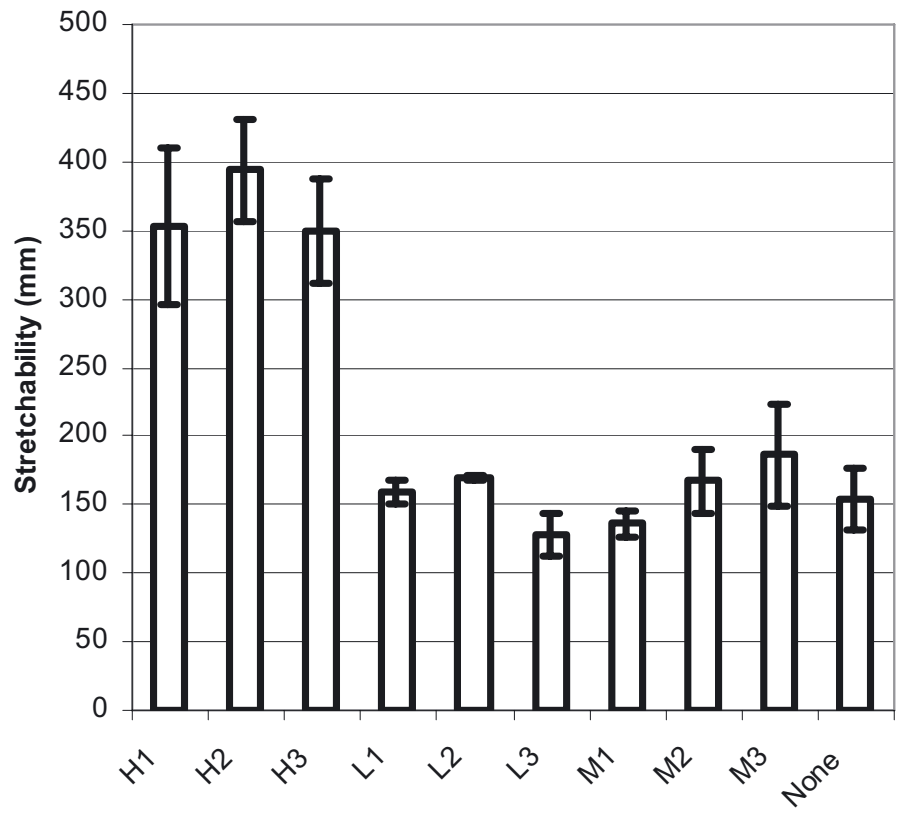

Thermophilic lactobacilli cultures

Figure 1. Influence of the Lactobacillus culture on the stretchability (mean $\pm \mathrm{SD}$ ) of ripened Swisstype cheeses (d49). H1, H2, H3: L. helveticus cultures; L1, L2, L3: L. delbrueckii subsp lactis cultures; M1, M2, M3: L. helveticus + L. delbrueckii subsp. lactis cultures; None: no lactobacilli added.

the latest stages of cheesemaking $(\Delta \mathrm{pH}=$ 0.08 after $6 \mathrm{~h}$ and 0.04 after $24 \mathrm{~h}$, respectively). As expected, the "L(+):D(-)lactate ratio" of the green cheeses differed depending on the Lactobacillus cultures: 1.0 ( \pm 0.17$)$ for L. delbrueckiii subsp. lactis (L-cheeses), 4.1 ( \pm 0.3$)$ for L. helveticus strains (H-cheeses) and $1.8( \pm 0.22)$ for mixed cultures (M-cheeses). For the mixed cultures, it can be estimated that the " $L$ delbrueckii:L. helveticus population ratio" in green cheeses was around 2:1 since $L$. helveticus strains produce about $70 \% \mathrm{~L}(+)$-lactate under Swiss cheese conditions [1].

At the end of the ripening (49 d) the experimental cheese had on average the following composition: Total solids 62.7 ( \pm 0.5\%), Fat-in-Dry-Matter 47.6
$( \pm 0.3) \%$, Moisture in Non-Fat Substance $53.6( \pm 0.5) \%$, Calcium/Non-Fat Solid $3.15( \pm 0.1) \%$ and Salt-in-Moisture 1.1 $( \pm 0.15) \%$. These values are in agreement with the data of Richoux et al. [20] for French Emmental cheese. There were no statistical differences between treatments.

\subsection{Influence of thermophilic lactobacilli cultures on the stretchability of the ripened cheeses}

The stretchability of the ripened cheeses ranged from 120 to $400 \mathrm{~mm}$, depending on the thermophilic strains and species (Fig. 1). Cheeses made with L. helveticus had a higher stretchability $(P<0.001)$ than L. delbrueckii subsp. lactis or mixed 


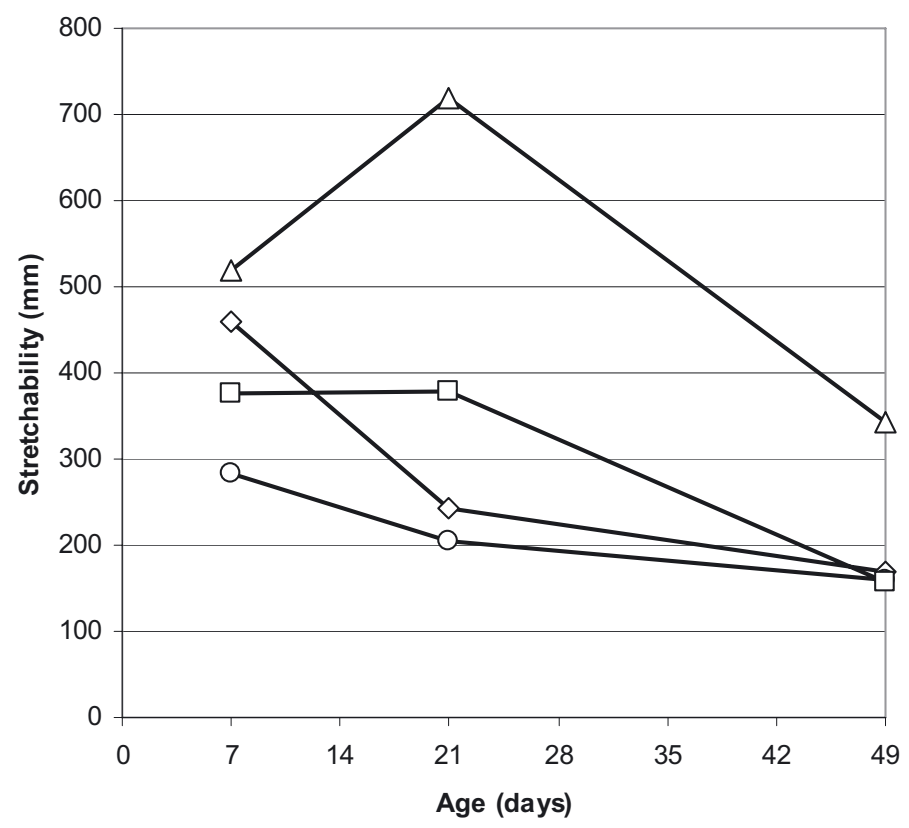

Figure 2. Changes in the stretchability of Swiss-type cheeses made with various lactobacillus cultures during ripening (mean values, $n=3$ ); $\triangle \mathrm{H} 1, \diamond \mathrm{L} 1, \circ \mathrm{L} 2, \square \mathrm{M} 1$.

cultures: $366( \pm 25) \mathrm{mm}$ vs. $152( \pm 21) \mathrm{mm}$ and $163( \pm 25) \mathrm{mm}$, respectively. The stretchability of Swiss-type cheeses manufactured without lactobacilli addition was similar to that of cheese containing L. delbrueckii subp. lactis. However, as expected, $\mathrm{pH}$ and casein breakdown were very different in these cheeses (data not shown).

\subsection{Evolution of the stretchability during ripening}

A kinetic study was performed with four cultures of thermophilic lactobacilli: H1, L1, L2 and M1. The changes in stretchability during ripening depended on the thermophilic lactobacilli used (Fig. 2). Both L. delbrueckii subsp. lactis strains yielded a progressive decrease in stretchability, the rate of decrease being more pronounced during cold room ripening.
On the contrary, the stretchability of the H1-cheeses increased markedly during cold room ripening and decreased at a high rate thereafter.

\subsection{Relationships between stretchability and proteolysis}

The results of proteolysis of the cheeses from the kinetic study are summarised in Table II. The variations between replicate trials were rather limited since standard deviations were below $0.3 \mathrm{~g} \cdot 100 \mathrm{~g}^{-1}$ for SN/TN and NPN/TN and below $0.9 \mathrm{~g} \cdot 100 \mathrm{~g}^{-1}$ for casein fractions. As expected, the age of cheeses was the main factor affecting the level of proteolysis. Lactobacillus strains had no measurable effect on the casein breakdown. Similar concentrations (calculated as \% of TN or $\%$ of $\mathrm{pH}$ 4.6-insoluble nitrogen) of non-degraded caseins, main macropeptides 
Table II. Proteolysis in Swiss-type cheese manufactured with various lactobacilli cultures (mean values, $n=3$ ).

\begin{tabular}{llcccccc}
\hline & & \multicolumn{7}{c}{ Nitrogen fractions (\% of total nitrogen) } \\
\hline & Culture & SN/TN & NPN/TN & $\gamma-\mathrm{CN}$ & $\beta-\mathrm{CN}$ & $\alpha \mathrm{s}_{1}-\mathrm{CN}$ & $\alpha \mathrm{s}_{1}-\mathrm{I}-\mathrm{CN}$ \\
\hline Day 7 & H1 & $7.7^{\mathrm{a}}$ & $2.7^{\mathrm{a}}$ & $8.3^{\mathrm{a}}$ & $22.0^{\mathrm{c}}$ & $36.7^{\mathrm{c}}$ & $2.0^{\mathrm{a}}$ \\
& L1 & $7.7^{\mathrm{a}}$ & $4.3^{\mathrm{c}}$ & $7.9^{\mathrm{a}}$ & $21.9^{\mathrm{c}}$ & $36.9^{\mathrm{c}}$ & $2.5^{\mathrm{ab}}$ \\
& L2 & $7.6^{\mathrm{a}}$ & $3.9^{\mathrm{b}}$ & $8.1^{\mathrm{a}}$ & $22.3^{\mathrm{c}}$ & $36.7^{\mathrm{c}}$ & $2.5^{\mathrm{ab}}$ \\
& M1 & $7.4^{\mathrm{a}}$ & $3.9^{\mathrm{b}}$ & $8.1^{\mathrm{a}}$ & $22.7^{\mathrm{c}}$ & $36.1^{\mathrm{c}}$ & $3.3^{\mathrm{b}}$ \\
Day 21 & H1 & $10.3^{\mathrm{b}}$ & $3.3^{\mathrm{ab}}$ & $10.0^{\mathrm{b}}$ & $18.9^{\mathrm{b}}$ & $28.1^{\mathrm{b}}$ & $3.4^{\mathrm{b}}$ \\
& L1 & $10.6^{\mathrm{b}}$ & $6.5^{\mathrm{e}}$ & $9.9^{\mathrm{b}}$ & $18.9^{\mathrm{b}}$ & $27.3^{\mathrm{b}}$ & $3.9^{\mathrm{bc}}$ \\
& L2 & $10.3^{\mathrm{b}}$ & $5.3^{\mathrm{d}}$ & $9.8^{\mathrm{b}}$ & $19.0^{\mathrm{b}}$ & $28.4^{\mathrm{b}}$ & $3.7^{\mathrm{bc}}$ \\
& M1 & $9.6^{\mathrm{b}}$ & $5.0^{\mathrm{d}}$ & $9.8^{\mathrm{b}}$ & $18.9^{\mathrm{b}}$ & $27.9^{\mathrm{b}}$ & $4.2^{\mathrm{c}}$ \\
& H1 & $21.9^{\mathrm{c}}$ & $11.0^{\mathrm{f}}$ & $13.8^{\mathrm{c}}$ & $12.3^{\mathrm{a}}$ & $15.0^{\mathrm{a}}$ & $12.1^{\mathrm{d}}$ \\
& H1 & $23.1^{\mathrm{d}}$ & $19.4^{\mathrm{h}}$ & $13.8^{\mathrm{c}}$ & $12.4^{\mathrm{a}}$ & $15.5^{\mathrm{a}}$ & $13.0^{\mathrm{d}}$ \\
& L2 & $23.1^{\mathrm{d}}$ & $16.6^{\mathrm{g}}$ & $14.4^{\mathrm{c}}$ & $11.2^{\mathrm{a}}$ & $16.4^{\mathrm{a}}$ & $12.5^{\mathrm{d}}$ \\
& L2 & $21.2^{\mathrm{d}}$ & $15.2^{\mathrm{g}}$ & $13.9^{\mathrm{c}}$ & $12.4^{\mathrm{a}}$ & $15.2^{\mathrm{a}}$ & $12.2^{\mathrm{d}}$ \\
\hline
\end{tabular}

a-h: Means in a column with common superscripts do not differ $(P>0.05)$.

$\left(\gamma\right.$-casein and $\alpha s_{1}$-I-casein) and secondary non-identified peptides (not shown) were obtained for all four cultures. However, small differences in secondary proteolysis (SN/TN, NPN/TN) occurred. Neither mean value per strain nor individual results of proteolysis were linked to the stretchability (data not shown). However, the stretchability was exponentially linked to the $(\mathrm{SN}-\mathrm{NPN}) / \mathrm{SN}$ ratio (or its betterknown complement NPN/SN), by the following equation (Fig. 3):

$$
\begin{gathered}
\text { Stretchability }(\mathrm{mm})=80.6 \mathrm{e}^{-3.0 \frac{(\mathrm{SN}-\mathrm{NPN})}{\mathrm{SN}}} \\
\mathrm{r}^{2}=0.78, n=36, P<0.001 .
\end{gathered}
$$

\subsection{Influence of the increase in primary proteolysis on the stretchability}

As expected [5], the hydrolysis of $\beta$-casein and the production of $\mathrm{pH} 4$.6-SN were increased by porcine plasmin addition to cheesemilk (Tab. III), while $\alpha s_{1}$ casein breakdown and NPN concentration remained unaffected. Stretchability of the cheeses with added plasmin was enhanced at $\mathrm{d} 7$ and $\mathrm{d} 21$. However, at the end of ripening (d49) a similar stretchability was obtained as in the control cheeses.

In this set of data, stretchability was also exponentially linked to the (SN-NPN)/SN ratio:

$$
\begin{gathered}
\text { Stretchability }(\mathrm{mm})=53.5 \mathrm{e}^{-4.0 \frac{(\mathrm{SN}-\mathrm{NPN})}{\mathrm{SN}}} \\
\mathrm{r}^{2}=0.70, n=27, P<0.001 .
\end{gathered}
$$

\section{DISCUSSION}

Stretchability is a major functional property of melted cheese. Proteolysis, and especially the proteolysis due to rennet activity, has been identified as the main factor which affects the evolution of the stretchability of Cheddar or Mozzarella cheeses during ripening. In Swiss cheese, however, the coagulant is denatured by cooking and the proteolysis is mainly due to plasmin and starter proteolytic activities. The aim of our study was to investigate the contribution of these factors to the stretchability of Swiss cheese. 


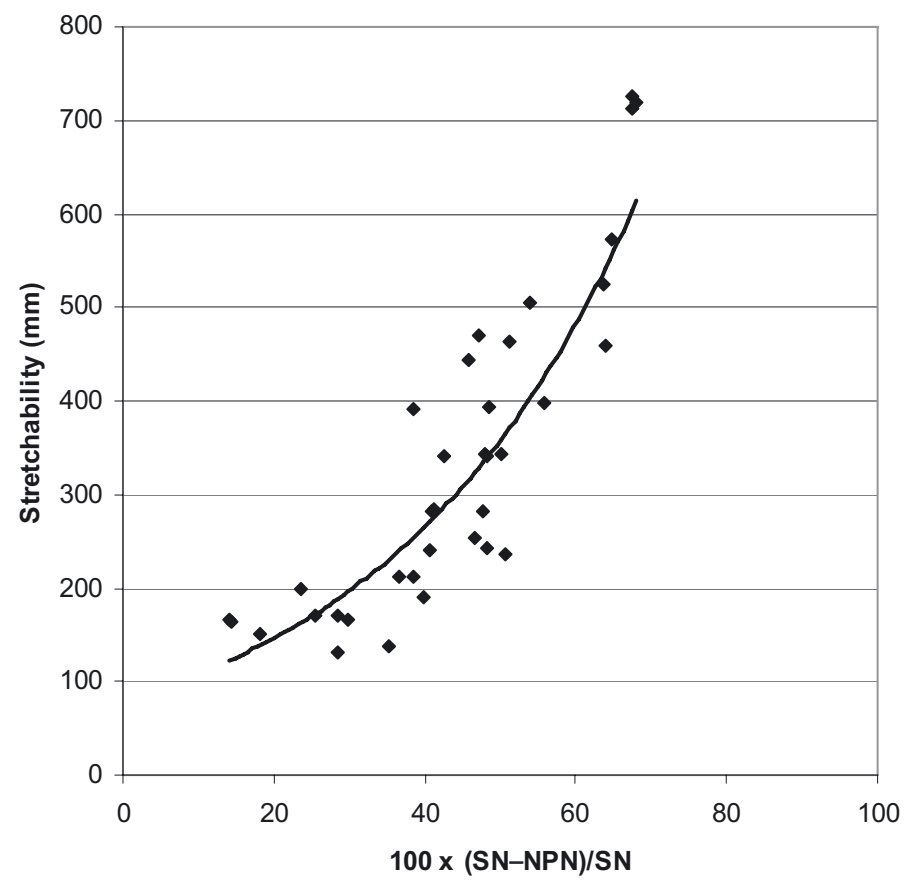

Figure 3. Relationships between stretchability and the proportion of hydrophobic peptides in $\mathrm{pH}$ 4.6-soluble nitrogen $[(\mathrm{SN}-\mathrm{NPN}) / \mathrm{SN}]$. Each dot represents an individual value $(n=36 ; 4$ strains, 3 ripening times, 3 replicates).

Table III. Proteolysis of Swiss-type cheeses made with or without added plasmin (mean values, $n=3$ ).

\begin{tabular}{|c|c|c|c|c|c|c|c|}
\hline & & \multicolumn{5}{|c|}{ Nitrogen fractions (\% of total nitrogen) } & \multirow{2}{*}{$\begin{array}{l}\text { Stretchability } \\
(\mathrm{mm})\end{array}$} \\
\hline & & SN & NPN & $\gamma-\mathrm{CN}$ & $\beta-\mathrm{CN}$ & $\alpha \mathrm{s}_{1}-\mathrm{CN}$ & \\
\hline \multirow[t]{3}{*}{ Day 7} & Control & $7.2^{\mathrm{a}}$ & $3.9^{\mathrm{a}}$ & $7.6^{\mathrm{a}}$ & $25.1^{\mathrm{e}}$ & $33.1^{\mathrm{c}}$ & $377^{\mathrm{c}}$ \\
\hline & $1.1 \mathrm{U} \cdot \mathrm{L}^{-1}$ plasmin & $8.5^{\mathrm{b}}$ & $4.4^{\mathrm{ab}}$ & $9.7^{\mathrm{b}}$ & $23.1^{\mathrm{d}}$ & $32.7^{\mathrm{c}}$ & $434^{\mathrm{d}}$ \\
\hline & $2.2 \mathrm{U} \cdot \mathrm{L}^{-1}$ plasmin & $9.4^{\mathrm{c}}$ & $4.5^{\mathrm{ab}}$ & $10.4^{\mathrm{b}}$ & $22.3^{\mathrm{d}}$ & $32.5^{\mathrm{c}}$ & $535^{\mathrm{e}}$ \\
\hline \multirow[t]{3}{*}{ Day 21} & Control & $9.4^{\mathrm{c}}$ & $5.0^{\mathrm{bc}}$ & $10.0^{\mathrm{b}}$ & $23.5^{\mathrm{d}}$ & $27.3^{\mathrm{b}}$ & $297^{\mathrm{b}}$ \\
\hline & $1.1 \mathrm{U} \cdot \mathrm{L}^{-1}$ plasmin & $10.7^{\mathrm{cd}}$ & $5.2^{\mathrm{bc}}$ & $10.4^{\mathrm{b}}$ & $21.1^{\mathrm{c}}$ & $27.1^{\mathrm{b}}$ & $333^{\mathrm{bc}}$ \\
\hline & $2.2 \mathrm{U} \cdot \mathrm{L}^{-1}$ plasmin & $11.3^{\mathrm{d}}$ & $5.5^{\mathrm{c}}$ & $12.0^{\mathrm{c}}$ & $20.1^{\mathrm{c}}$ & $26.9^{\mathrm{b}}$ & $535^{\mathrm{e}}$ \\
\hline \multirow[t]{3}{*}{ Day 49} & Control & $21.2^{\mathrm{e}}$ & $15.1^{\mathrm{d}}$ & $12.4^{\mathrm{c}}$ & $15.4^{\mathrm{b}}$ & $11.4^{\mathrm{a}}$ & $156^{\mathrm{a}}$ \\
\hline & $1.1 \mathrm{U} \cdot \mathrm{L}^{-1}$ plasmin & $21.5^{\mathrm{e}}$ & $15.0^{\mathrm{d}}$ & $13.6^{\mathrm{d}}$ & $14.9^{\mathrm{b}}$ & $10.7^{\mathrm{a}}$ & $174^{\mathrm{a}}$ \\
\hline & $2.2 \mathrm{U} \cdot \mathrm{L}^{-1}$ plasmin & $23.2^{\mathrm{f}}$ & $15.3^{\mathrm{d}}$ & $15.1^{\mathrm{e}}$ & $12.6^{\mathrm{a}}$ & $10.6^{\mathrm{a}}$ & $163^{\mathrm{a}}$ \\
\hline
\end{tabular}

${ }^{\mathrm{a}-\mathrm{f}}$ : Means in a column with common superscripts do not differ $(P>0.05)$. 
The stretchability of our experimental cheeses was in the range of that of the commercial French Emmental cheeses analysed by Richoux et al. [20]. In this survey, the stretchability ranged from 80 to $950 \mathrm{~mm}$ and $90 \%$ of the values were lower than $400 \mathrm{~mm}$. As described in other cheese varieties [8], the stretchability of our experimental cheeses globally decreased during ripening, showing eventually an optimum.

Our results show that thermophilic lactobacilli greatly influence the stretchability of Swiss cheese, since a three-fold variation can be seen among the strains. In agreement with the results of Wyder [22] in Raclette cheese, L. helveticus yielded higher stretchability than $L$. delbrueckii subsp. lactis and mixed culture of both species. The association of $L$. delbrueckii subsp. lactis with L. helveticus decreased the cheese stretchability (Fig. 1). Based on the "L(+):D(-)-lactate ratio" of the green cheeses, it can be estimated that the L. helveticus counts were three-fold lower in mixed cultures than in $L$. helveticus cheeses. Specific peptides involved in stretchability could have been produced in lower amounts due to a weaker $L$. helveticus population. More probably, these peptides could have been hydrolysed by aminopeptidases of L. delbrueckii subsp.. lactis.

A few studies have described the effect of the thermophilic lactobacilli on cheese stretchability, mainly LMPS Mozzarella cheese. These works suggested that the "stretchability potential" of the strains depends on (i) their quantitative proteinasic activity, (ii) the specificity of their cellwall proteinase, and (iii) their peptidasic activity $[11,16,17]$. This specificity was not studied in our experiments and its determination could be helpful to understand the mechanisms involved in stretchability. However, L. helveticus and L. delbrueckii subsp. lactis differ in both their proteinase and peptidase activities, as illustrated by the RP-HPLC pattern of peptides observed in Swiss cheese [2]. A complete characterisation of the proteolytic equipment and of the autolytic properties of the strains would probably be required to understand their potential to enhance stretchability.

Plasmin addition did not alter the stretchability of the ripened Swiss-type cheeses although it was affected at the early stages of ripening. Similarly, Somers et al. [21] found little effect of the stage of lactation on the stretchability of LMPSMozzarella. However, only M1 culture was tested in our study and interactions between plasmin activity and lactobacillus culture have to be studied.

In agreement with the findings of other authors [9], we did not establish direct relationships between stretchability and classical nitrogen fractions of cheeses. However, the stretchability of Swiss cheese was linked to the hydrophobic moiety of $\mathrm{pH} 4$.6-soluble peptides since $12 \%$ TCA-fractionation excludes long hydrophobic peptides [24]. Similar relationships between the $(\mathrm{SN}-$ NPN)/SN ratio and stretchability were obtained when testing either four lactobacillus cultures with constant milk plasmin activity or three levels of plasmin activity with one lactobacillus culture. Similarly, the (12\% TCA-SN)/(Water-SN) ratio has been correlated to strain at fracture during uniaxial compression of various Swiss-type varieties [4]. High compression rates at fracture (i.e. the empirical longness of cheese) was associated with weak (12\% TCA-SN)/(Water-SN). More recently, Wyder [22] related differences in sensorial characteristics (viscosity, longness and firmness) of melted Raclette cheese made with various lactic starters to the content of (Water-SN)-(12\% TCA-SN) of cheeses.

From these results, we suggest that, besides mineral bonds [8], hydrophobic bonds could be involved in the mechanism of stretchability. Considering their size and concentration in cheese, it seems 
very unlikely that such hydrophobic peptides could form the backbone of the strands of cheese. However, they could be involved in the formation of the fibres of protein by helping the establishment of hydrophobic bonds between intact caseins or macropeptides. Alternatively, they could be only an indicator of the presence of specific macropeptides that would form the strings, although urea-PAGE of $\mathrm{pH}$ 4.6insoluble nitrogen did not reveal differences between strong and weak stretching cheeses (data not shown). The hydrophobic $\mathrm{pH}$ 4.6-soluble peptides could also reflect an optimal microstructure for strand formation.

However, the hydrophobic $\mathrm{pH}$ 4.6soluble fraction was not correlated to stretchability when expressed as percent of total nitrogen. For example, some ripened cheeses with weak stretchability showed the same $[(\mathrm{SN}-\mathrm{NPN}) / \mathrm{TN}]$ ratio as some green cheeses with strong stretchability. This suggests that the peptide composition of this nitrogen fraction plays a crucial role in the stretchability. Alternatively, the balance between hydrophobic and hydrophilic peptides could be determinant.

The answer to these questions will probably help to explain the fundamental mechanisms of string formation in the future. Although our study does not permit this explanation, it gives, besides the well-known impact of cheese mineralisation [8], operating levers to modulate the stretchability of Swiss cheese.

\section{CONCLUSIONS}

These preliminary results show that the choice of thermophilic lactobacilli culture is a key factor for the stretchability of Swiss cheese, stronger stretchability being observed with L. helveticus cultures. Qualitative rather than quantitative aspects of proteolysis are determinant for the development of this functional property.
In particular, hydrophobic soluble peptides or the balance between hydrophobic and hydrophilic peptides seem to be a critical point. Further studies are now required to understand the mechanisms involved in the formation of these peptides and their contribution to cheese stretchability.

Acknowledgements: This research was funded by Brittany Council and the SIGF (Syndicat Interprofessionnel du Gruyère Français, Paris, France).

\section{REFERENCES}

[1] Chamba J.F., L'emmental, un écosystème complexe. Conséquences sur la sélection et 1'utilisation des ferments, Sci. Aliment 20 (2000) 37-54.

[2] Chopard M.A., Schmitt M., Perreard E., Chamba J.F., Aspect qualitatif de l'activité protéolytique des lactobacilles thermophiles utilisés en fabrication de fromages à pâte pressée cuite, Lait 81 (2001) 183-194.

[3] Collin J.C., Berdagué J.L., Dognin-Bergeret M., Grappin R., Muttoni M.P., RoletRepecaud O., Affinage et qualité du Gruyère de Comté, IV. Étude de la protéolyse, Lait 67 (1987) 299-318.

[4] Eberhard P., Rheologische Eigenschaften ausgewählter Käsesorten, Dissertation ETH Zürich Nr. 7836, 1985.

[5] Grappin R., Beuvier E., Bouton Y., Pocher S., Advances in the biochemistry and microbiology of Swiss-type cheeses, Lait 79 (1999) 3-22.

[6] Gripon J.C., Desmazeaud M., Le Bars D., Bergère J.L., Étude du rôle des microorganismes et de leurs enzymes dans la maturation des fromages, II. Influence de la présure commerciale, Lait 55 (1975) 502-516.

[7] Guggisberg D., Bütikofer U., Albrecht B., Melting and solidification characteristics of Swiss Raclette cheese measured by small amplitude oscillatoty shear measurements, J. Texture Stud. 38 (2007) 297-323.

[8] Guinee T.P., The functionality of cheese as an ingredient: a review, Aust. J. Dairy Technol. 57 (2002) 79-91.

[9] Guinee T.P., Feeney E.P., Fox P.F., Effect of ripening temperature on low moisture Mozzarella cheese: 2 . Texture and functionality, Lait 81 (2001) 475-486. 
[10] Heiss E., Versuche zur Bestimmung des Käsefettgehaltes mit Hilfe von Schnellmethoden, Deutsche Molkerei Zeitung 82 (1961) 67-70.

[11] Hong Y.H., Yun J.J., Barbano D.M., Larose K.L., Kindstedt P.S., Mozzarella cheese: impact of three lactobacillus culture strains on composition, proteolysis and functional properties, Aust. J. Dairy Technol. 53 (1998) 163-169.

[12] International Dairy Federation, Determination of nitrogen content, Standard $n^{\circ} 20$, IDF, Brussels, Belgium, 2001.

[13] International Dairy Federation, Cheese and processed cheeses. Determination of the total solid content, Standard n ${ }^{\circ}$, IDF, Brussels, Belgium, 2004.

[14] International Dairy Federation, The World market of cheese, Bulletin of the IDF $n^{\circ} 402$, 2005

[15] Mead D., Roupas P., Effect of denatured whey proteins on chemical composition and functionality of pizza cheese, Aust. J. Dairy Technol. 56 (2001) 19-23.

[16] Oberg C.J., Wang A., Moyes L.V., Brown R.J., Ricardson G.H., Effect of proteolytic activity of thermolactic cultures on physical properties of Mozzarella cheese, J. Dairy Sci. 74 (1991) 389-397.

[17] Oomen B.S., McMahon D.J., Oberg C.J., Broadbent J.R., Strickland M., Proteolytic specificity of Lactobacillus delbruekii subsp. bulgaricus influences functional properties of Mozzarella cheese, J. Dairy Sci. 85 (2002) 2750-2758.

[18] Pearce K.N., The complexometric determination of calcium in dairy products, N. Z. J. Dairy Sci. Technol. 12 (1977) 113-115.

[19] Richoux R., Kerjean J.R., Caractérisation technologique de souches pures de bactéries propioniques : test en minifabrication de fromages à pâte cuite, Lait 75 (1995) 45-59.

[20] Richoux R., Roset G., Famelart M.H., Kerjean J.R., Diversité de quelques propriétés fonctionnelles à chaud de 1'Emmental français, Lait 81 (2001) 547-559.

[21] Somers J.M., Guinee T.P., Kelly A.L., The effect of plasmin activity and cold storage of cheese milk on the composition, ripening and functional properties of Mozzarellatype cheese, Int. J. Dairy Technol. 55 (2002) 5-11.

[22] Wyder M.T., Einsatz von Lactobacillus helveticus in der Raclette-Fabrikation, FAMInformation $\mathrm{n}^{\circ}$ 49, Agroscope Liebefeld Posieux, Bern, Switzerland, 2001.

[23] Yun J.J., Barbano D.M., Kiely L.J., Kindstedt P.S., Mozzarella cheese: impact of rod:coccus ratio on composition, proteolysis and functional properties, J. Dairy Sci. 78 (1995) 751-760.

[24] Yvon M., Chabanet C., Pelissier J.P., Solubility of peptides in trichloracetic acid (TCA) solutions, Int. J. Pept. Protein Res. 34 (1989) 166-176. 